FACTA UNIVERSITATIS

Series: Law and Politics Vol. 16, N 3, 2018, pp. 163-172

https://doi.org/10.22190/FULP1803163I

Original Scientific Paper

\title{
EXERCITOR AND MAGISTER NAVIS IN ROMAN LAW *
}

UDC 347.79(37)

\section{Marija Ignjatović}

Faculty of Law, University of Niš, Serbia

\begin{abstract}
The legal position of the owner of a vessel (exercitor navis) and the captain of a vessel (magister navis) was not always precisely defined in Roman law. A number of factors had an influence on it, and the most important one was the development of the maritime trade, which had a direct impact on this issue. At the beginning of its development, taking into account its insufficiently developed navigation, it is clear that there was no need for defining the legal position of the vessel owner and the captain of a vessel and establishing the difference between them. Since the navigation was primitive in the first phases of the development of maritime sailing, it was necessary for the vessel owner to monitor his vessel during a journey and look after all the goods he was entrusted with and passengers who were transported. With the development of maritime trade, especially in the classical period, they started to perceive the vessel owner and the captain of a vessel as two separate roles, which necessarily called for clearly and precisely defining their legal position, i.e. the clear distinction of the rights and obligations of a person who was the owner of a vessel and a person who was entrusted with operating the vessel. In the post-classical period, the general decadence which was omnipresent in the Roman society generated the decadence in the navigation, which had a number of negative reflections. One of them was merging the roles of the owner and the captain of a vessel in one person again. In order to better understand the positive effects of the situation when the ship owner was also the captain of that ship in the period of the late republic, as well as the negative effects of merging these two roles into one which occurred in the Dominate period, this paper will address the question of the legal position of exercitor navis and magister navis during three periods of the development of Roman law: the last centuries of the late Republic, the classical period and the postclassical period.
\end{abstract}

Key words: exercitor navis, magister navis, late Republic period, classical period, postclassical period.

Received December 11 $1^{\text {th }}, 2018$ / Accepted December $20^{\text {th }}, 2018$

Corresponding author: Prof. Marija Ignjatović, LL.D, Associate Professor, Faculty of Law, University of Niš, Trg kralja Aleksandra 11, 18000 Niš, Republic of Serbia

E-mail: marija@prafak.ni.ac.rs

${ }^{*}$ The study is a result of research on the project Harmonizing Serbian Law with the Law in the European Union which is financed by the Faculty of Law, University of Nis, for the period 2013-2018. 


\section{INTRODUCTION}

The legal position of the owner of a vessel (exercitor navis) and the captain of a vessel (magister navis) in Roman law was one of the extremely interesting issues in Roman law because it was an integral part of the development of maritime trade in Rome.

The development of maritime trade in the Roman state occurred during the period after the conquest of Carthage, when Romans started to rule over the entire Mediterranean area and when they conquered northern and southern Gaul. In the newly conquered countries, they established their colonies (provinces) and built traffic connections for unhindered development of trade (primarily for the transportation of wheat and marble). The occupation of neighbouring nations after the Punic wars, the suppression of pirates at sea, and using military roads exclusively for commercial purposes (Stojčević, 1947: 47) made it possible to come into contact with different cultures and different goods (Stojčević, 1947: 47). ${ }^{1}$ Most of the objects were made for the needs of local population, but there were certain regions of the Empire which specialized in producing particular products, for which reason merchants used to travel long distances, sometimes even beyond the borders of the Empire.

The survival of certain regions of the Empire, known for their local products, was the result of the Roman conquering policy. When they conquered the neighbouring countries, Romans did not destroy their cultures. They only stopped their further development, and included them in the Roman war, commercial and state machine (Ignjatović, 2002: 328). That significantly increased Roman production forces and the general culture level, which became especially noticeable in the case of maritime trade. Thus, conquering the Mediterranean made the world more connected than it had ever been before. Roman ships sailed everywhere from the Mediterranean, over the Black and the Red sea, to the Indian Ocean, in the west along the coast of modern Morocco, in the northwest to Britain, but the centre of navigation had always been the Mediterranean (the Roman sea) (Marquardt, 1892: 19-30). In these circumstances, the whole Mediterranean area, almost the complete ancient world, became a big commercial area (Stojčević, 1947: 47).

It is understandable that maritime trade, especially in the beginning, did not develop in the same way as it had developed during the period of classical law. Although Romans were famous in legal science for their legal ingenuity, legal logic, interpretation, formation and creation of law in accordance with practical needs (Ignjatović, 2016: 325-338), it is unlikely that they were the first creators of legal rules of maritime trade since they were not remembered as a maritime nation in history; maritime trade was developed a long time before the Romans by the Hellenic nation whose maritime law (lex Rhodia de iactu) was developed in the IX century BC (Ignjatović, 2017: 186) ${ }^{2}$. However, thanks to the reception of the maritime law of the island of Rhodes, which happened after they had conquered this island, Romans were ready for the development of maritime trade. The existence of the basis of maritime law offered an opportunity to further develop this field of law, particularly in the part related to transportation industry. Thus, in order to understand and comprehend certain principles related to the issue which is the topic of this paper, it is

\footnotetext{
${ }^{1}$ At the same time, there were two other significant trade-related developments: money and credit.

${ }^{2}$ This legislation developed under the strong influence of the Phoenicians, who were the most important traders in the ancient world. The Phoenician influence was prominent in Rhodes, which had been their colony for a long time. The Rhodian maritime code (lexRhodia de iactu) has never been found but, according to the works of Roman historians, it dates back to 475-479 BC. This legislation was later incorporated in the Roman legislation, and, from there, into Byzantine law.
} 
necessary to establish certain time frame within which it would be observed. For this reason, in this paper, the issue of the legal position of the owner of a vessel and the captain of a vessel will be observed through all three periods in the development of Roman maritime law: the last centuries of the late Republic period, the classical period, and the postclassical period.

\section{Exercitor navis and magister navis in the late Republic period}

In the beginning of the development of maritime trade, maritime transport was done by pater familias himself - the owner of a ship (exercitor navis). That was the period when the functions of the owner and the captain of a vessel were united in one person, primarily because it was more economical (Šarac, 2008: 85), ${ }^{3}$ On the other hand, in this period, the dominant principle was still alteri stipulari nemo potest, which meant that only pater familias was the one who could look after his cargo during the journey, arrange legal affairs independently and organize a sailing venture, accepting full responsibility for all the benefits as well as for the incurred damage.

The rule alteri stipulari nemo potest was particularly obeyed by the Romans of the upper social classes, who supported the attitude that the direct participation of persons alieni iuris and slaves in legal affairs was beneath their dignity. However, although that was the prevailing attitude, the legal practice at the end of the $3^{\text {rd }}$ century BC, and especially at the end of the $2^{\text {nd }}$ century $\mathrm{BC}$, showed that the heads of families were willing to share profit of business performed by persons alieni iuris or slaves; they justified it by the fact that they were the owners of these slaves, referring to the provisions of the ancient Roman law which included that possibility.

Gai. Inst. 2.86: ADQUIRITUR AUTEM NOBIS NON SOLUM PER NOSMET IPSOS, SED ETISM PER EOS QUOS IN POTESTATE MANU MANCIPIOVE HABEMUS; ITEM PER EOS SERVOS, IN QUIBUS USUM FRUCTUM HABEUS; ITEM PER HOMINES LIBEROS ET SERVOS ALIENOS QUOS BONA FIDE POSSIDEMUS. DE QUIBUS SINGULIS DILIGENTER DISPICIAMUS (Translation: Stanojević, 2009: 122-123) ${ }^{4}$

Thus, it was becoming more and more common that persons alieni iuris and slaves appeared as contracting parties that arranged certain legal affairs for pater familias by his order. Nevertheless, the participation of alieni iuris persons and slaves in legal-economic transactions generated some legal uncertainty since, in the beginning, no one wanted to do business and to arrange legal affairs with these persons because they did not have their own property, and the owner was not bound in this way. Since the principle alteri stipulari nemo potest had a dominant role, if there were people who arranged such business, they were not able to claim receivables in any way (Šarac, 2011: 45) since it was a matter of natural obligations (obligations naturalles) which could not be enforced by judicial action, but they could be claimed.

On the other hand, the fast development of legal-economic transactions, especially at the end of the period of the Republic, called for some changes in a particular direction.

\footnotetext{
${ }^{3}$ In the period of undeveloped navigation, the owner of a vessel monitored his vessel himself, arranged and managed affairs related to its operation, management and maintenance.

${ }^{4}$ Gai.Inst. 2.86 (translation: Stojanovic, 2009: 122-123): "We get our supplies not only by our own actions, but also by actions of other people, persons alieni iuris and slaves, regardless of whether they acquire them by means of a contract or inherited them."
} 
The appearance of private property and its accumulation were suitable for the new circumstances, as well as the introduction of traditio as an informal way of gaining property, which made it possible to have fast transactions, by gaining property a manu in тапи. The liberation of trade from strict formalism, which had been present previously in the form of mancipatio, made it necessary to narrow the scope of the legal capability of pater familias, in favour of persons alieni iuris and slaves. Actually, the more prominent need of pater familias to arrange a large number of legal affairs with different contracting parties and in different places at the same time made it necessary to narrow the scope of his legal capacity in favour of persons alieni iuris and slaves.

The new situation demanded additional activity of the praetor, meaning that there was a need for new, more flexible solutions which would, in a way, depart from the strict rule alteri stipulari nemo potest which started to increasingly interfere with the need for fast legal-economic development. As a result of the praetor's efforts, they reached a solution by introducing six new lawsuits (actions adiecticiae qualitatis), which precisely defined the situations in which both persons alieni iuris and slaves could appear and make

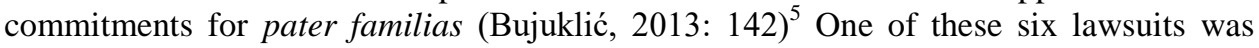
actio exercitoria, which defined the responsibility of pater familias in case he entrusted a person alieni iuris or a slave with the management of his vessel. The introduction of this lawsuit was precisely the moment when they started to draw a distinction between the roles of exercitor navis (the owner of a vessel) and magister navis (the captain of a vessel) who was entrusted with operating the vessel.

\section{Exercitor and magister navis in the classical period}

In the history of Rome, the classical period is remembered as a period of general prosperity. When it comes to trade, it was the period of a great expansion to the east; Roman merchants exploited not only Asia Minor but they also crossed the Suez Canal, and travelled as far as China. The general development of trade, therefore, did not allow for rigid solutions and strict forms. The need for quick and efficient ways of arranging legal affairs created the need for the participation of other persons in legal-economic transactions, whose engagement would enable the pater familias to arrange a great number of legal affairs in different places at the same time. Since one of the basic principles of the Roman law of obligations was alteri stipulari nemo potest (i.e. that no one could be contractually obliged if he did not participate in making that contract), the solution for the fast turnover of goods was the praetor's introduction of actions adiecticiae qualitatis. In this way, he established the responsibility of the pater familias in cases where he was not present during the arrangement of legal affairs, because he was sometimes far away from the place of making a contract.

From the aspect of maritime trade, the introduction of actio exercitoria in maritimelaw relations in the $2^{\text {nd }}$ century $\mathrm{BC}$ led to faster transactions in maritime trade, and it also brought consensualism of the classical period to the fore, which was embodied in the will of exercitor, expressed in praepositio ${ }^{6}$, to name the captain of a vessel (magister navis).

\footnotetext{
${ }^{5}$ From Lat.adiecticius - added, the name given by medieval jurists (glossators) because the obligations which they produced were "added" to the primary responsibility of pater familias.

${ }^{6}$ Praepositio - one-sided legal business in which exercitor appointed a certain person as the captain of a vessel and at the same time he implicitly took responsibility to the third party that he would accept all the obligations accepted by the captain of a vessel, as if he was present during the arrangement of legal business
} 
Expressing the freedom of will that, in certain legal affairs related to the transportation of goods and passengers by sea, an appointed person could act according to the orders of the owner of a vessel (exercitor navis), represented the fulfilment of the need for fast legaleconomic transactions, since the other contracting party did not waste time seeking information about a captain and his qualities, but was only focused on what was stated in praepositio (the person named the captain of a vessel and the scope of his authorization). Thus, exercitor was the manager in the company: "ad quem obventiones et reditus omnes perveniunt sive is dominus navis sit, sive a domino navem per aversionem conduxerit vel ad tempus vel in perpetuum" (Brunetti, 1929: 109) The complete authorization related to the organization and management of a vessel was united in his personality; thus, magister navis was an expression of his will to entrust the vessel management to a certain person.

D.14.1.1.1. (Ulp. 28 ad ed): MAGISTRUM NAVIS ACCIPERE DEBEMUS, CUI TOTIUS NAVIS CURA MANDATA EST.

The exercitor usually chose one of his alieni iuris persons or slaves for the captain of his vessel (magister navis) (Romac, 1994: 835). ${ }^{7}$ Under Roman law, apart from these persons, it was also possible to appoint a free person (who hired a vessel) as the captain, who did maritime transport professionally for his own benefit and who had responsibilities to the third party related to his obligations in maritime business (Pezelj, 2017: 315)

Gai, Inst. 4.71: EADEM RATIONE CONPARAVIT DUAS ALIAS ACTIONES, EXERCITORIAM ET INSISTORIAM. TUNC AUTEM EXERCITORIA LOCUM HABET, CUM PATER DOMINUSVE FILIUM SERVUMVE MAGISTRUM NAVI PRAEPOSUERIT, ET QUID CUM EO EIUS REI GRATIA CUI PRAEPOSITUS FUERIT GESTUM ERIT. CUM ENIM EA QUOQUE RES EX VOLUNTATE PATRIS DOMINIVE CONTRAHI VIDEATUR, AEQUISSIMUM ESSE VISUM EST IN SOLIDUM ACTIONEM IN EUM DARI. QUIN ETIAM, LICET EXTRANEUM QUISQUAE MAGISTRUM NAVI PRAEPOSUERIT SIVE SERVUM SIVE LIBERUM, TAMEN EA PRAETORIA ACTIO IN EUM REDDITUR. (Translation: Stanojević, 2009: 318-319). ${ }^{8}$

Although Roman law, especially after introducing actio exercitoria, offered a possibility to appoint not only a person alieni iuris but also a slave as the captain of a vessel, it rarely happened in practice (Romac, 1973: 481) ${ }^{9}$ Namely, the risk was too big in this case; there was a possibility that a slave would run away, because it was not possible to monitor a slave (Šarac, 2008: 93) In that case, exercitor navis was exposed to a great loss taking into consideration the value of a ship, ship equipment, crew and cargo. Therefore, that might be one of the reasons why the texts of the ancient Roman law did

\footnotetext{
${ }^{7}$ Taking into consideration the fact that in the first stages of the development of maritime trade Romans did not have much experience, they usually entrusted maritime work to slaves of the Greek or Oriental origin.

${ }^{8}$ Gai, Inst. 4.71 (translation: Stojanovic, 2009: 318-319): "For the same reason two other lawsuits were given: exercitoria and insistoria. Actio exercitoria was implemented when a father or a master appointed his son or slave as the captain of a vessel and someone arranged business with him, which was related to his position. Namely, as it was considered in this case that the business was arranged in accordance with the will of the father or master, it was completely just to file a suit against him for the total value of the debt, even though the commander of a vessel was a person that did not belong to that family, either someone else's slave or a free man, and it was possible to bring actio exercitoria against him (the head of a family).

${ }^{9}$ In case that a slave was appointed as captain of a vessel, it was usually a slave of Greek or Oriental origin, given the fact that they were educated people who had certain maritime knowledge and skills.
} 
not offer a single real proof that it was necessary to appoint a person alieni iuris or a slave as the captain of a vessel; but, in some texts, like in the above cited source written by Gaius, it was stated that it could be a foreigner (extraneus). Ulpianus shared the same attitude.

D. 14.1.4. (Ulp. 28 ad ed): CUIUS AUTEM CONDICIONIS SIT MAGISTER ISTE, NIHIL INTEREST, UTRUM LIBER AN SERVUS, ET UTRUM EXERCITORIS AN ALIENUS:SED NEC CUIUS AETATIS SIT, INTERERIT, SIBI IMPUTATURO QUI PRAEPOSUIT. ${ }^{10}$

"The captain had to be not only the person who exercitor trusted most but also a very educated person. The commander of a ship determined the course of the ship, because of which he had to have maritime knowledge and skills; it often depended on his skilfulness whether the ship, cargo and passengers would survive a storm or a pirate attack. Apart from that, in order to have control over his crew, he had to be a respected and authoritative person" (Šarac, 2008: 94). From all the aforesaid, it may be concluded that the common practice was to appoint either a person alieni iuris or a free citizen as captain of a vessel (magister navis), who was entrusted with managing the vessel, while the complete responsibility was placed on the owner of a vessel (exercitor) and it was estimated in solidum (Horvat, 1998: 236). ${ }^{11}$

In this context, there is another interesting attitude given by Ulpianus who, referring to Julianus' attitude, pointed out that the captain of a vessel was not only the person appointed by exercitor but also the person appointed by the captain of a vessel himself (magister navis). In that case, the owner of a vessel (exercitor) was also responsible for the work of the promagister, because the basic attitude was that the exercitor had to know that the promagister had been appointed by the captain and it was supposed that he had approved it. According to Ulpianus, even if the exercitor explicitly opposed it, he was responsible for general safety of all the participants of a sailing venture (Šarac, 2008:123) In addition, the exercitor could appoint more than one person as the captain of a vessel, and in that case every single person had his own duties. The most common duties of the captain of a vessel were renting a ship, loading and unloading goods, the transportation of passengers, buying ship equipment, etc. For all these tasks, the exercitor was responsible in solidum, because they relied on the praepositio where all these duties were specifically stated, so that they represented the will of the exercitor.

The introduction of this type of responsibility was necessary, inter alia, because it represented the basis for the relationship of trust between providers and recipients of service of maritime transportation in the classical period.

\section{Exercitor and magister navis in the postclassical period}

The postclassical period in the history of the Roman state was characterized as a period of the decline of the slave-holding system and the emergence of the feudal system. The Dominate period was marked by a general decadence in the Roman society. A group of authors used political reasons to explain the problem of decadence, claiming that

\footnotetext{
${ }^{10}$ D. 14.1.4. (Ulp. 28 ad ed): 'The legal status of a captain had no significance; it was not important if he was a free person or a slave and, if he was a slave, whether he belonged to exercitor or to someone else. His age was not important either, since it was something that a person who appointed him should take care of'.

${ }^{11}$ Most probably, appointing a free person as the captain of a vessel started in the classical period and that was not the case in the period of introducing actiones adiecticiae qualitatis.
} 
pretenders to the emperor's throne were focused on the power-related issues and fought long and exhausting battles with each other, which resulted in the weakening of the defence capacity of the state and its collapse when it faced the attacks of barbaric tribes. Other authors, however, found the explanation for this in moral and spiritual decline of the Roman society in the Dominate period, pointing out to the weakening of old Roman traditions and virtues, as well as the decline of paternal authority and other fundamental Roman law institutions (Boras, Margetić, 1980: 211).

The most significant consequence which the Roman Empire had to face in this period, due to economic and other types of decline, was certainly their return to agricultural production. All branches of economy which had existed up to that point (crafts, trade, transportation, mining, etc.) ceased to exist if they were not useful for agriculture (Lot, 1927: 62-64). ${ }^{12}$ It also had a direct influence on the drastic reduction of turnover and trade; on the other hand, it affirmed the already started process of naturalization. The general tendency was a return to a closed home production, whose pivotal point was a large estate which was the core of general social events. This type of economy was incompatible with commodity production, which led to the weakening and total collapse of middle-sized estates, which did not have any conditions for further survival.

Due to such developments, state authorities started to lose their power as they were no longer able to stand against the increasingly prominent process of naturalization. The tendency of increasing the number of large estates led to the emergence of coloni, independent farmers, who became part of large estates, either willingly or because of specific circumstances, and this strengthened the role of estate owners. According to Beaudoin, the estate owner was a sort of iudex privatus, which was opposite to the principles applicable in the late Roman Empire. Yet, besides the existing prohibitions, he still had full power which was a consequence of weakening of the state (on the one hand) and strengthening of estates (on the other hand) (Beaudoin, 1889: 71). Thus, large estates started to get more economic independence and autonomy, and gathered people from a larger area (Romac, 1966: 62) ${ }^{13}$

The instability of money, putting all branches of economy (crafts, trade, transportation, mining, etc.) at the service of agriculture and the unsafety of sailing at sea had a direct influence on the changing legal position of exercitor and magister navis. Unlike the previous periods, it did not have its foundation in voluntas exercitora, but it was based on the safety of sailing at sea and the protection of passengers' interests. In that regard, it is understandable why in this period, in order to protect their interests before making a contract, the other contracting party had to obtain information about the captain of a vessel and the scope of his authorization, as well as about what it had been stated in the praepositio. In addition, they had to obtain information about the person exercitor and weather he would be responsible for obligations from the arrangements made by authorized persons in his name.

As it can be noticed, in the postclassical period, with the decline of the maritime Mediterranean transportation, the classical figure of the exercitor disappeared. It is safe to say that in this period the situation was the same as the one at the beginning of the development of maritime sailing, i.e. the exercitor and the magister navis were again joined

\footnotetext{
${ }^{12}$ Anarchy, which appeared in the Dominate period, was a period of violence, robberry, unsafety of life and property, and it led to almost complete disappearance of trade and exchange in certain areas.

13 "Occasionally, this behaviour of Roman noblemen was interpreted as a loss of the collective awareness and a lack of care for the interests of the empire as a whole, and the reasons for this were seen in different influences, some of which were the influence of Christianity and the church, the change in the social structure of the upper classes of the society, the disappearance of rectitude of the old Rome, and similar reasons." (Romac, 1966: 62)
} 
in one and the same person. Actually, ius exercitoria started to disappear, which can be explained by the collapse of navigation. On the other hand, due to the collapse of navigation, it happened that primarily smaller ships with small cargo travelled at sea; hence, for reasons of economic profitability, the owner of a vessel and the technical manager of the expedition were joined in the same person (Brunetti, 1929: 110). ${ }^{14}$

Due to general circumstances in the state at that time, the emphasis was put on the safety of sailing and the protection of passengers' interests, and not on the voluntas of a ship operator. Considering that fact, praepositio resembled an authorization for representation. The will expressed in praepositio was concretized by the magister navis, when he arranged particular legal business, which means that he was primarily guided by his free will. On the other hand, Roman law kept the basic principle that the person who accepted the obligations was the one who made a contract (alteri stipulari nemo potest), which meant that an intermediary who made a contract also accepted some obligations. On the basis of the aforesaid, it may be concluded that, in this period, the captain of a vessel (magister navis) still did not have authorization for representation, legally speaking. He arranged business in his own name and he became a contracting partner. On the other hand, given the fact that the magister navis was authorized by the exercitor's will, the exercitor was bound by the contract but he was responsible only if the magister did not exceed his authorization. For this reason, when arranging legal affairs, the other contracting party had to pay attention to personal qualities of the magister as well as to personal qualities and interests of the exercitor.

\section{CONCLUSION}

Taking everything into consideration, it may be concluded that the legal position of the owner of a vessel (exercitor) and the captain of a vessel (magister navis) was not equally treated in all phases of the development of the Roman maritime law. Namely, with the development of maritime trade after the Punic wars and the conquest of the Mediterranean, the rule was that the owner of a vessel had to be on board during the journey and to look after the vessel, since it was more economical; thus, he was supposed to reap the benefits of his vessel but also to suffer negative consequences.

On the other hand, the ruling principle alteri stipulari nemo potest did not allow that any other person make commitments for an owner. However, with the development of trade in general, and especially with the development of maritime trade, the old forms became rigid and started to impede the fast development of legally economic dealings. Although the prevailing attitude of Romans that belonged to the upper social classes was that the participation of alieni iuris persons and slaves in arranging legal affairs was beneath the dignity of pater familias, the practice from the end of the $3^{\text {rd }}$ and $2^{\text {nd }}$ century $\mathrm{BC}$ showed that it was becoming more and more common for these people to arrange legal affairs for the heads of families, who were thus willing to share profit.

For the given reasons, the new situation required the praetor's fast intervention and his actions led to reaching solutions suitable for the fast turnover of goods and services. In his Edict, the praetor prescribed the introduction of actiones adiecticiae qualitatis,

\footnotetext{
${ }^{14}$ The loss of ius exercitoria was one of the reasons why in later laws, and especially in pseudo-Rodian law, there was no mention of the classical figure of exercitor.
} 
which, viewed from the aspect of maritime trade, enabled persons alieni iuris and slaves to manage a vessel by order of pater familias, i.e. to be appointed captain of a vessel (magister navis). This point in the development of maritime trade was the breakthrough moment when the function of the owner of a vessel (exercitor) started to be differentiated from the function of the captain of a vessel (magister navis). On the other hand, this moment was in accordance with the spirit of the classical period, when the will was favoured as an important element of a contract. Due to that, the owner of a vessel could be kilometres away from the place where the contract was made between the captain of a vessel and the other contracting party. It was enough that he stated his unequivocal will that a certain person should be appointed as captain of a vessel in preapositio, unilateral legal business. At the same time, by this act, he implicitly made a commitment to the third party that he would assume all obligations taken by the captain of the vessel, as if he attended the arrangement of a particular legal affair. The legal ground of his responsibility was ius exercitoria, and, in case of a failure to abide by the agreement, the third party could invoke the exercitor's liability on the basis of actio exercitoria.

In the postclassical period, with the general decadence of the Roman society, the roles of the exercitor and magister navis merged again in one person. The decline of navigation and the reappearance of pirates at sea led to the situation that the ships that travelled at sea were mostly small ones with small cargo. Thus, for the reason of economic feasibility, the roles of the owner of a vessel and the technical manager of the expedition were united in the same person. The difference is that, in the period of starting maritime trade, the merging of the exercitor and magister navis was the result of the beginning of its development, while in the classical period, this merging was the result of declining and the general decadence which led to the disappearance of the exercitor and its replacement with the person nauclero in the late preclassical period.

\section{REFERENCES}

Beaudoin, E . (1889). Les grands domains dans l'Empire Romain, Nouvelle revue historique de droit francais et etranger, 1889.

Boras, M.; Margetić, L. (1980). Rimsko pravo, Pravni fakultet, Zagreb.

Brunetti, A. (1929). Diritto marittimo privato Italiano, Torinese, Torino.

Bujuklić, Ž. (2013). Rimsko privatno pravo, Pravni fakultet Univerziteta u Beogradu, Beograd,

Horvat, M. (1998). Rimsko pravo, Pravni fakultet, Zagreb,

Ignjatović, M. (2017). Actio furti et damni adversus nautas kao oblik osiguranja putnika na brodu, Zbornik radova sa međunarodne naučne konferencije "Suvremeni izazovi pomorske plovidbe", Split, 29. - 30. septembar 2017, Pravni fakultet Sveučilišta $u$ Splitu.

Ignjatović, M. (2016). Da mihi facto, dabo tibi ius (stvaranje, kreiranje, tumačenje i primena prava u starom Rimu), Zbornik na trudovi, Treta medjunarodna konferencija „Opštestveni promeni vo globalniot svet“, Praven fakultet, Štip.

Ignjatović, M. (2002). Zaštita ljudskih i manjinskih prava u doba rimske republike, Zbornik radova Pravnog fakulteta Univerziteta u Nišu, br. 62, tematski broj "Zaštita ljudskih i manjinskih prava u evropskom pravnom prostoru", Pravni fakultet, Niš.

Lot, F. (1927). La fin du monde antique et le debut du Moyen Age, La Renaissance du Livre, Paris.

Marquardt, K.J. (1892). La Vie privee des Romains, E. Thorin, Paris.

Pezelj, V. (2017). Patronus navis u dalmatiskom statutarnom pravu, Zbornik radova sa međunarodne naučne konferencije "Suvremeni izazovi pomorske plovidbe", Split, 29 -30. septembar 2017, Pravni fakultet Sveučilišta $u$ Splitu.

Romac, A. (1966). Rimska privreda i proces njene naturalizacije, Anali Pravnog fakulteta u Beogradu, Pravni fakultet u Beogradu.

Romac, A. (1973). Izvori rimskog prava, Informator, Zagreb. 
Romac, A. (1994). Justinijan.Institucije (prevod), Latina et Graeca, Zagreb. Stanojević, O. (2009). Gai Institutiones, II, 86. Gaj-Institucije (prevod), Zavod za udžbenike, Beograd

Šarac, M. (2008). Actio exercitoria, u: Zastupanje u pravnim poslovima u rimskom pravu, Pravni fakultet Sveučilišta u Splitu, Split, str. 85-103.

Šarac, M. (2008). Magister navis, u: Zastupanje u pravnim poslovima u rimskom pravu, Pravni fakultet Sveučilišta u Splitu, Split, str.115-125.

Šarac, M. (2011). Mandatum u rimskom pravu (monografija), Naklada Bošković, Split.

Stojčević, D. (1947). Rimsko pravo, I deo: društveno-ekonomski uslovi pod kojima se razvijalo rimsko pravo, statusno, porodično, stvarno, nasledno i krivično, Beleške po predavanjima održanim u škol. 1945/46, Odbor za udžbenike stručnog udruženja studenata prava Beograd.

\section{EXERCITOR NAVIS AND MAGISTER NAVIS U RIMSKOM PRAVU}

Pravni položaj vlasnika broda (exercitor navis) i kapetana brodara (magister navis), nije bio oduvek precizno definisan u rimskom pravu. Na njega je uticalo niz faktora, a najznačajniji činilac koji je imao direktne refleksije na ovo pitanje, bio je sam razvoj pomorske trgovine. U prvim danima razvoja, imajući $u$ vidu nedovoljno razvijenu plovidbu, razumljivo je bilo što se pitanje definisanja $i$ razlike u pravnom položaju vlasnika broda i kapetana brodara nije ni postavljalo. Sa razvojem trgovine uopšte, a posebno sa razvojem pomorske trgovine, stari obrasci postali su kruti i počeli su da ometaju brz razvoj pravno-ekonomskog prometa. Iako je kod Rimljana iz viših društvenih slojeva dugo preovladavalo shvatanje da je učešće lica alieni iuris i robova u zaključivanju pravnih poslova ispod svakog dostojanstva pater familiasa, praksa s kraja III i II veka pre nove ere govori o tome da su sve češći bili primeri gde su ova lica zaključivala pravne poslove za starešine porodica, koji su pak na ovaj način rado delili profite.

Ključne reči: exercitor navis, magister navis, period kasne republike, klasični period principata, postklasični period dominata 